\title{
Relationship between porosity, permeability and pore compressibility
}

\author{
Marco Ceia, Roseane Missagia, Ricardo Fasolo, Irineu Lima Neto, UENF/LENEP
}

Copyright 2019, SBGf - Sociedade Brasileira de Geofísica

This paper was prepared for presentation during the $16^{\text {th }}$ International Congress of the Brazilian Geophysical Society held in Rio de Janeiro, Brazil, 19-22 August 2019.

Contents of this paper were reviewed by the Technical Committee of the $16^{\text {th }}$ International Congress of the Brazilian Geophysical Society and do not necessarily represent any position of the SBGf, its officers or members. Electronic reproduction or storage of any part of this paper for commercial purposes without the written consent of the Brazilian Geophysical Society is prohibited.

\section{Abstract}

Pore compressibility is one the key properties in reservoir characterization. Such importance is because it influences other properties as porosity, permeability, seismic velocities and rock rigidity. Hence, the knowledge of pore compressibility and the understanding of the mechanism of how it affects the other properties are decisive for several activities in reservoir exploration, management and production.

This work aims to address the influence of pore compressibility on porosity and permeability using experimental data analysis for providing empirical models that relate those properties. The results indicated that power-law models are appropriate for explaining such inter-dependence and bounced that pore compressibility as the key factor to describe the behavior of porosity and permeability of the rocks under external pressure.

\section{Introduction}

Pore compressibility is one of the most important petrophysical properties and can influence storage capacity, fluid movement and geomechanical behavior of the reservoir rocks. Tiab and Donaldson (2012) showed that neglecting that parameter can mislead the estimates of volume of oil-in-place. Those authors also addressed the effect of the external pressure in the porosity of the rocks.

Dobrynin (1962) (apud Tiab and Donaldson, 2012) linked pore compressibility to porosity for explaining the variation on that latter, regarding the changes in the confining pressure. Most recently, Silva Jr. et al. (2015) and Oliveira et al. (2016) studied the relationship between pore compressibility and porosity on rocks extracted from outcrops in USA and Brazil. The first work used Mercury Injection Capillary Pressure Porosimetry (MICP) while the second used pore volume measurements through Helium gas expansion technique.

Early works relating pore compressibility and permeability were developed by McLatchie et al. (1958) and Dobrynin (1962). Different from the relationship to porosity, there are few works addressing the relationship pore compressibility and permeability in the literature up to date (Dobrynin, 1962, Dong et al., 2010).

This work aims to provide new insights of the dependence of porosity and permeability to pore compressibility through the analysis of experimental data on core plugs.

\section{Theory}

Geertsma (1957) significantly contributed for the comprehension of the pressure-volume relationship in porous reservoir rocks. He introduced the concept of three types of compressibility: bulk $\left(C_{b}\right)$, matrix $\left(C_{m}\right)$ and pore $\left(C_{p}\right)$. The determination of $C_{b}$ and $C_{m}$ uses relatively simple techniques of rock volumetric deformation.

$C_{p}$ can be obtained through two different approaches. One is to evaluate pore compressibility as a porous pressure function, "simulating" the production process of a reservoir, in which as the depletion occurs, the pore volume is reduced. In those experiments the confining pressure is kept constant. This type of pore compressibility is usually referred as $C_{p p}$. The second approach is to measure the porous space variation when the sample is submitted to different confining pressures, but keeping pore pressure constant. This type is referred as $C_{p c}$ and is usually associated with the volumetric variation of rock samples when they are brought to surface after coring. Despite the phenomenological differences between those two compressibilities, both are dependent on effective pressure and can be related one to another (Jaeger et al., 2007). Zimmerman et al. (1986) re-derived the relationships between different compressibilities and in terms of the confining and pore pressure. The pore compressibility as a function of the confining pressure is defined as:

$$
C_{p c}=-\frac{1}{V_{p}}\left(\frac{\partial V_{p}}{\partial P}\right)_{P p}
$$

\section{Method}

An Ultrapore-300 helium gas expansion Porosimeter was used to measure grain volume and grain density. A digital caliper allowed the measuring of the length and diameter of the cylindrical samples enabling to estimate the bulk volume and then calculate pore volume and porosity. Operational procedures were performed according to API, 1998.

A poroperm instrument (Coreval 700) was used to perform pore volume (PV) measurements and to determine rock permeability at different confining pressures. The pore volume was inferred through gas 
$\left(\mathrm{N}_{2}\right)$ expansion technique (API, 1998) while permeability was evaluated through an unsteady state technique known as pressure falloff (Jones, 1972).

The same equipment also measured the length of the core plugs at each pressure stage using a linear potentiometric transducer with $0.01 \mathrm{~mm}$ accuracy. Those measurements can be used for estimating the vertical strain of the rocks.

Porosity was estimating using Eq. 2 and considering that the grain volume $(\mathrm{GV})$ remained unaltered during those experiments.

$$
\phi=\frac{P V}{(P V+G V)}
$$

Pore compressibility was estimated through the method described by Unalmiser and Swalwell (1991), which consists in fitting a power-law curve relating the pore volume variation upon external pressure, and estimate Cpc using the derivative of that power-law function (Eqs. 3-5).

$$
\begin{gathered}
V_{p}=a P_{c}^{-b} \\
\frac{\partial V_{p}}{\partial P_{c}}=-a b P_{c}^{-b-1} \\
C_{p c}=\frac{-b}{P_{c}}
\end{gathered}
$$

\section{Rock Samples}

We used a set of 9 rock samples consisting in 6 sandstones and 3 carbonates extracted from outcrops in the USA. Table 1 lists the mineral content of those rocks according to other works in the literature.

\section{Results}

Figure 1 shows the variation of the pore volume as function of the confining pressure for the rock samples. A first-order power-law fitting (Eq. 3) is likely to describe very well such behavior presenting coefficients of determination $\left(R^{2}\right)$ greater than 0.82 . Such values as also the coefficients of the power-law are listed in Table 2.

Pore compressibility was estimated using Eq. 5 and the coefficient $b$ listed in Table 2. A crossplot between those values and the confining pressure is displayed in Figure 2.

Figure 3 shows a comparison between the results of pore compressibility of Berea and Boise sandstones obtained in this work and extracted from other works in literature. That comparison aimed to check how close are our results, which were obtained using gas porosimetry under hydrostatic conditions, to the results obtained with other methodologies. For Berea the results are consistent with Zimmerman (1984) and Oliveira et al. (2015). The first performed $\mathrm{C}_{\mathrm{pc}}$ measurements on brine-saturated samples by measuring the rock deformation using strain gauges and measuring the expelled brine. The latter used pore volume measurements obtained through $\mathrm{He}$ gas expansion technique, but at uniaxial stress condition. $\mathrm{C}_{\mathrm{pc}}$ were calculated using the Unalmiser-Swalwell method.

For Boise sandstone, the results are very similar to the reported by Zimmerman (1984).

The relationship between porosity $(\phi)$ and pore compressibility is exhibited in Figure 4 . Such behavior can be expressed through a second-order power-law fitting (Eq. 6).

$$
\phi=f\left(C_{p c}\right)^{g}+h
$$

The coefficients $f, g$ and $h$ are listed in Table 3 . Those regressions resulted in $\mathrm{R}^{2}$ ranging from 0.976 up to 0.999 .

Crossplots between the logarithm of gas permeability and pore compressibility as shown as in Figure 5 allowed evaluating the relationship between those properties. The best fitting resulted in a second-order power-law expression (Eq. 7).

$$
\log (k)=m\left(C_{p c}\right)^{n}+o
$$

The coefficients $\mathrm{m}, \mathrm{n}$ and $\mathrm{o}$ are exhibited in Table 4. Such fitting presented $R^{2}$ ranging between 0.708-0.995.

\section{Discussions}

The power-law regressions are likely to fit the behavior of the pore volume due to confining pressure variation with $\mathrm{R}^{2}$ ranging from 0.824 to 0.992 . Idaho sandstone exhibited the worst fitting. Figueiredo (2015) presented Mercury Injection Porosimetry (MIP) results obtained in similar samples and reported that pore sizes ranging from 10-100 $\mu \mathrm{m}$. Possibly, those larger pore sizes are associated to post-diagenetic events. Kahl et al. (2016) showed results of X-ray micro-CT obtained in this kind of rock and reported weathered minerals as feldspar and muscovite. The images presented by those authors showed large non-rounded grains and a variety of poreshapes. These features may lead to a deviation from the expected power-law trendline in the pore volumepressure curve.

Porosity is likely to have a great dependence on pore compressibility. A second-order power-law equation perfectly describes such dependence, characterized by the high values of $R^{2}(<0.97)$. Such power-law model also describes the relationship between absolute permeability and pore compressibility, but differently than $\phi$-Cpc behavior, the $R^{2}$ values were smaller for some of the samples, indicating that other factor may influence permeability rather than solely the pore compressibility on those rocks. Even though, $67 \%$ of the samples reported $\mathrm{R}^{2}$ greater than 0.9 highlighting the feasibility of that power-law model.

The coefficients of those power-law equations are specific for each sample. Probably they are associated to certain characteristics of the rock, such as mineral content, 
unconfined porosity, pore-shape distribution and aspect ratio.

\section{Conclusions}

This work showed that such porosity as absolute permeability can be related to pore compressibility through power-law models. The high accuracy of those models indicates that pore compressibility has a major influence on the variations of porosity and permeability when the rocks are submitted to external pressure.

Although the coefficients of those expressions vary for different rocks, perhaps such models may be used for estimating pore compressibility or even absolute permeability from well log data, if calibrated coefficients were available.

\section{Acknowledgments}

Authors thank UENF / LENEP for all environment and structure provided to the execution of this work. This study was financed in part by the Coordenação de Aperfeiçoamento de Pessoal de Nível Superior - Brasil (CAPES) - Finance Code 001. RF thanks PRH-226Petrobras for his MSc scholarship. MC and RM thanks INCT/Geofisica and PRH-226-Petrobras for financial support; and also, CNPq for their Research Grants of Productivity in Technological Development and Innovation - DT II. We are also very grateful to Luiz Abreu for helping during the experiments and Dr. Nicholas Haudidier for technical assistance and valuable discussions.

\section{References}

API, 1998. Recommend Practices for Core Analysis. RP40. American Petroleum Institute. $2^{\text {nd }}$ Edition.

DOBRYNIN, VM. 1962. Effect of overburden pressure on some properties of sandstones. Soc. Petrol. Eng. J. 3606.

DONG, JJ, HSU, JY, WU, WJ, SHIMAMOTO, T, HUNG, JH, YEH, EC, WU, Y-H, Sone, H. 2010. Stressdependence of the permeability and porosity of sandstone and shale from TCDP Hole-A. Int. J. Rock Mech. Min. Sci. 47 (7), 1141-1157.

FIGUEIREDO, LAB. 2015. Avaliação do Sistema Poroso e Estimativa de Permeabilidade utilizando equações modificadas de Kozeny em rochas siliciclásticas e carbonáticas. MSC Dissertation. UENF/LENEP. Macaé, Brazil. (In Portuguese).

GEERTSMA, J. 1957. The effect of fluid pressure decline on volumetric changes of porous rocks. Petroleum Transactions, AIME, v. 210, p. 331-340.
JAEGER, J, COOK, N \& ZIMMERMAN, R. 2007. Fundamentals of Rock Mechanics. Wiley-Blackwell.

JONES, SC. 1972. A Rapid Accurate Unsteady-State Klinkenberg Permeameter. Society of Petroleum Engineers Journal. SPE3535-PA. p. 383-397. October.

KAHL, WA., HANSEN, C \& BACH, W. 2016. A new X-ray transparent flow-through reaction cell for a $\mu$-CT-based concomitant surveillance of the reaction progress of hydrothermal mineral- fluid interactions. Solid Earth, 7, 651-658. doi: 10.5194/se-7-651-2016.

MANHÃES, DKP. 2018. Petrophysical Hysteresis properties analysis based on chemical, textural and pore structure characteristics of sedimentary rocks. MSc Dissertation. UENF/LENEP. Macaé, Brazil.

MCLATCHIE, AS, HEMSTOCK, RA \& YOUNG, JW. 1958. The Effective Compressibility of Reservoir Rock and Its Effects on Permeability. 32 ${ }^{\text {nd }}$ Annual Fall Meeting of Society of Petroleum Engineers. Dallas, USA. SPE 894-G.

OLIVEIRA, GLP, CEIA, MAR., MISSAGIA, RM, ARCHILHA, NL, FIGUEIREDO, L, SANTOS, VH \& LIMA NETO, I. 2016. Pore volume compressibilites of sandstones and carbonates from Helium porosimetry measurements. J. App. Geophys. 137,185-201. doi: 10.1016/j.petrol.2015.11.022

SILVA JR., GP, FRANCO, DR, STAEL, GC, LIMA, MCO, MARTINS, RS, FRANÇA, OM \& AZEREDO, RBV. 2015. Petrophysical studies of North American carbonate rock samples and evaluation of pore-volume compressibility models. J. App. Geophys. 123, 256-266. doi: 10.1016/j.jappgeo.2015.10.018

TIAB, D. \& DONALDSON, E. 2012. Petrophysics. Theory and Practice of Measuring Reservoir Rock and Fluid Transport Properties. $3^{\text {rd }}$. Ed. Elsevier.

UNALMISER, S \& SWALWELL, TJ. 1993. A quick technique to define Compressibility Characteristics of Hydrocarbon Reservoir. SPE Rocky Mountain Regional/Low Permeability Reservoirs Symposium. Denver, USA. SPE 25912.

ZIMMERMAN, RW. 1984. The Effect of Pore Structure on the Pore and Bulk Compressibilities of Consolidated Sandstones. PhD. Thesis. University of California, Berkeley.

ZIMMERMAN, RW, SOMERTON, WH \& KING, MS.1986. Compressibility of porous rocks. J. Geophys. Res. 91,12765-12777. doi: 10.1029/ JB091iB12p12765. 
Table 1: Mineral content of the rock samples (in \%) and lithologies obtained through other works.

\begin{tabular}{|c|c|c|c|c|c|c|c|c|c|c|c|c|c|}
\hline Sample & Calcite & Quartz & Dolomite & Albite & Biotite & Kaolinite & Orthoclase & Plagiocase & Feldspar & Mica & Clinoptilolite & Lithology & Reference \\
\hline Berea & & 91 & & & & 4 & & 1 & 3 & & & Sandstone & \begin{tabular}{|l} 
Kokurek \\
$(2019)$
\end{tabular} \\
\hline Boise & & 49 & & & & & & 29 & 12 & 5 & 4 & Sandstone & \begin{tabular}{|l}
$\begin{array}{l}\text { Kokurek } \\
(2019)\end{array}$ \\
\end{tabular} \\
\hline $\begin{array}{l}\text { Indiana } \\
\text { Limestone }\end{array}$ & 99.9 & 0.1 & & & & & & & & & & Limestone & $\begin{array}{l}\text { Manhães } \\
(2018)\end{array}$ \\
\hline Winsconsin & 0.7 & 16.3 & 83 & & & & & & & & & Dolomite & $\begin{array}{l}\text { Figueiredo } \\
(2015)\end{array}$ \\
\hline Nugget & & 72.34 & & & 7.91 & 6.79 & 12.96 & & & & & Sandstone & $\begin{array}{l}\text { Manhães } \\
(2018)\end{array}$ \\
\hline Colton & 5.16 & 64.24 & 9.22 & 9.23 & & 12.14 & & & & & & Sandstone & $\begin{array}{l}\text { Manhães } \\
(2018)\end{array}$ \\
\hline Crab Orchard & & 93 & & & & & & & 0.95 & 6.05 & & Sandstone & $\begin{array}{l}\text { Figueiredo } \\
(2015)\end{array}$ \\
\hline $\begin{array}{l}\text { Edward } \\
\text { Yellow }\end{array}$ & 99.7 & 0.3 & & & & & & & & & & Limestone & \begin{tabular}{|l} 
Figueiredo \\
$(2015)$
\end{tabular} \\
\hline Idaho & & 49 & & & & & & 29 & 12 & 5 & 4 & Sandstone & $\begin{array}{l}\text { Kokurek } \\
(2019)\end{array}$ \\
\hline
\end{tabular}
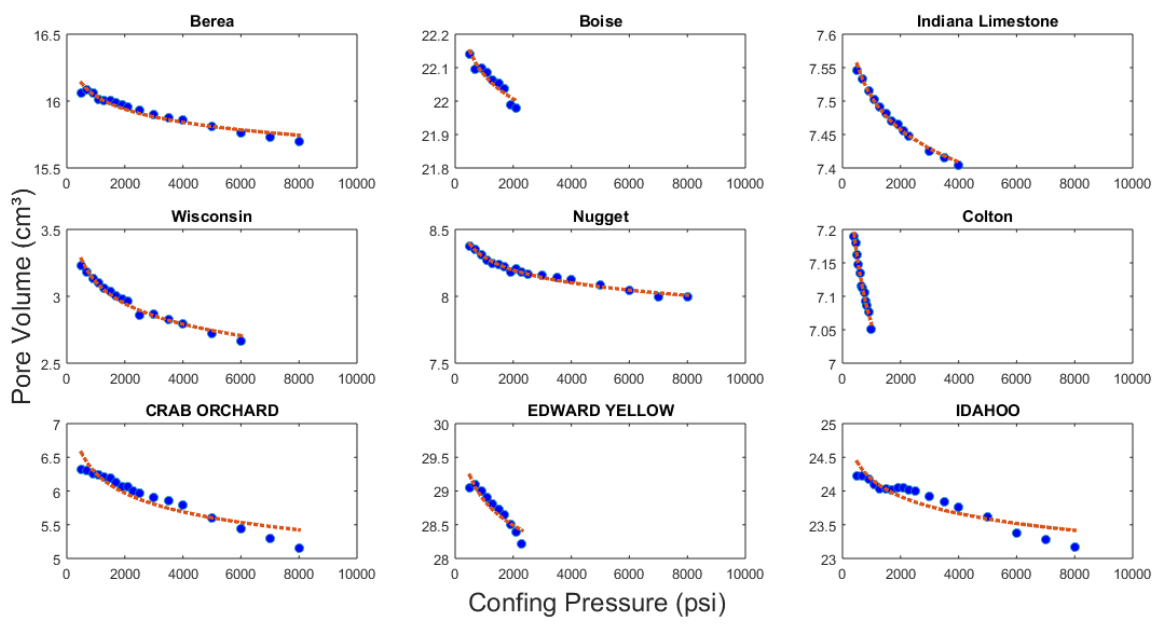

Figure 1: Crossplot between pore volume and confining pressure (blue dots). Red dashed line represents a power-law fitting.

Table 2: Coefficients and $\mathrm{R}^{2}$ of the first-order power-law fitting showed on Fig. 1.

\begin{tabular}{|l|r|r|r|}
\hline Sample & a & \multicolumn{1}{l|}{ b } & $\mathrm{R}^{2}$ \\
\hline Berea & 17.048 & -0.0089 & 0.947 \\
\hline Boise & 22.803 & -0.0047 & 0.886 \\
\hline Indiana Limestone & 8.010 & -0.0094 & 0.992 \\
\hline Winsconsin & 5.299 & -0.0773 & 0.977 \\
\hline Nugget & 9.315 & -0.0168 & 0.985 \\
\hline Colton & 8.145 & -0.0207 & 0.990 \\
\hline Crab Orchard & 10.096 & -0.0691 & 0.867 \\
\hline Edward Yellow & 32.805 & -0.0185 & 0.850 \\
\hline Idaho & 26.877 & -0.0153 & 0.824 \\
\hline
\end{tabular}



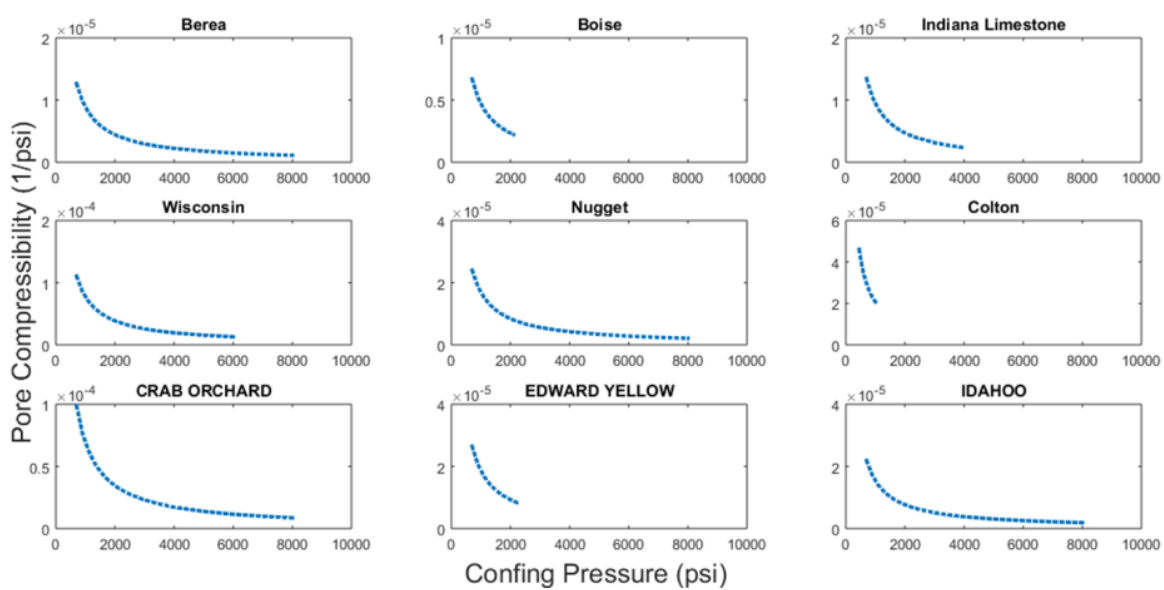

Figure 2: Crossplot between pore compressibility (estimated using Unalmiser-Swalwell technique) and confining pressure.
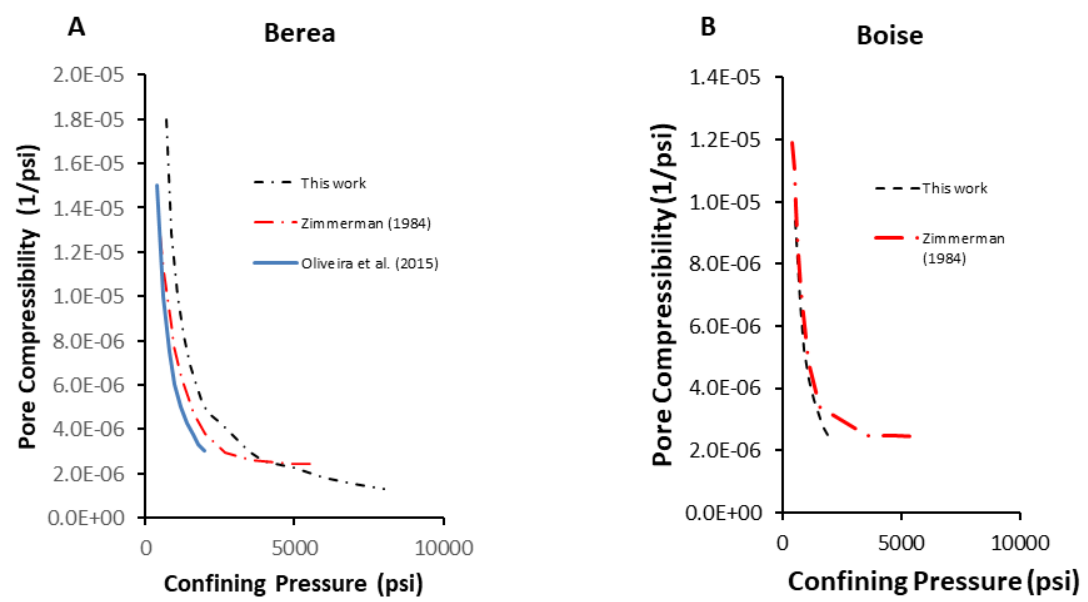

Figure 3: Crossplot between pore compressibility and confining pressure for various works.
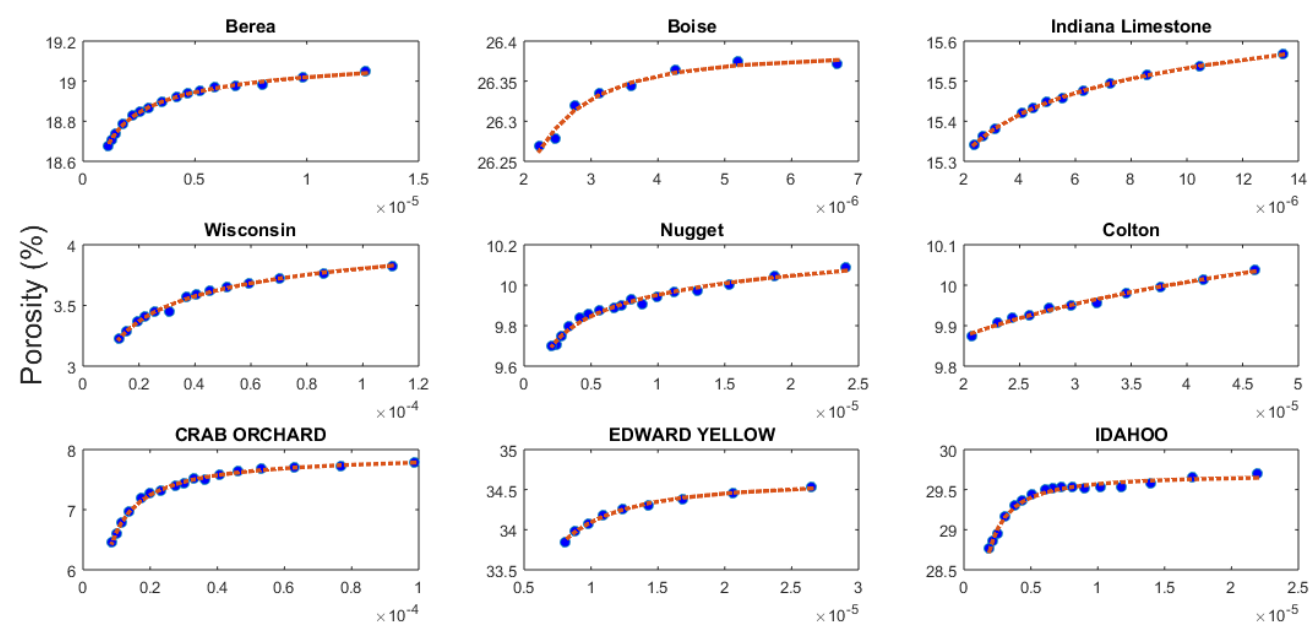

Pore Compressibility (1/psi)

Figure 4: Crossplot between porosity and pore compressibility (blue dots). Red dashed line represents a second-order power-law fitting. 
Table 3: Coefficients and $R^{2}$ of the power-law fitting showed on Fig. 4.

\begin{tabular}{|l|l|r|r|r|}
\hline Sample & a & b & c & $\mathrm{R}^{2}$ \\
\hline Berea & $-1.53 \mathrm{E}-03$ & -0.430 & 19.236 & 0.997 \\
\hline Boise & $-4.17 \mathrm{E}-16$ & -2.559 & 26.384 & 0.976 \\
\hline Indiana Limestone & $-8.97 \mathrm{E}-02$ & -0.174 & 16.201 & 0.999 \\
\hline Winsconsin & $-1.54 \mathrm{E}-01$ & -0.211 & 4.883 & 0.992 \\
\hline Nugget & $-2.07 \mathrm{E}-01$ & -0.140 & 10.987 & 0.986 \\
\hline Colton & $-7.28 \mathrm{E}-01$ & -0.096 & 11.941 & 0.989 \\
\hline Crab Orchard & $-3.87 \mathrm{E}-05$ & -0.906 & 7.948 & 0.997 \\
\hline Edward Yellow & $-2.46 \mathrm{E}-09$ & -1.665 & 34.619 & 0.996 \\
\hline Idaho & $-8.42 \mathrm{E}-08$ & -1.234 & 29.695 & 0.983 \\
\hline
\end{tabular}
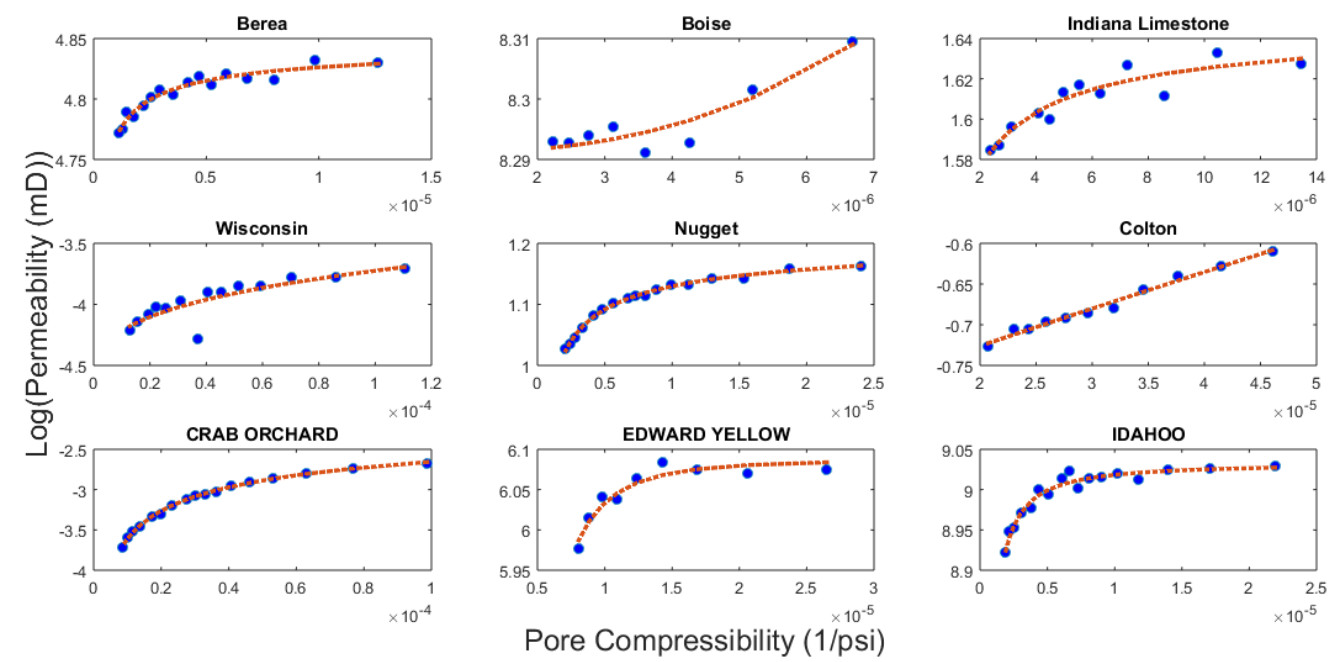

Figure 5: Crossplot between the log of gas permeability and pore compressibility (blue dots). Red dashed line represents a second-order power-law fitting.

Table 4: Coefficients and $\mathrm{R}^{2}$ of the power-law fitting showed on Fig. 5.

\begin{tabular}{|l|r|r|r|r|}
\hline Sample & \multicolumn{1}{|l|}{$\mathrm{m}$} & $\mathrm{n}$ & $\mathrm{O}$ & $\mathrm{R}^{2}$ \\
\hline Berea & $-7.51 \mathrm{E}-05$ & -0.508 & 4.852 & 0.948 \\
\hline Boise & $9.12 \mathrm{E}+11$ & 2.648 & 8.291 & 0.873 \\
\hline Indiana Limestone & $-1.54 \mathrm{E}-05$ & -0.649 & 1.652 & 0.879 \\
\hline Winsconsin & $1.56 \mathrm{E}+01$ & 0.299 & -4.716 & 0.708 \\
\hline Nugget & $-5.65 \mathrm{E}-04$ & -0.452 & 1.233 & 0.995 \\
\hline Colton & $2.65 \mathrm{E}+03$ & 0.943 & -0.824 & 0.986 \\
\hline Crab Orchard & $-1.25 \mathrm{E}-01$ & -0.249 & -1.418 & 0.997 \\
\hline Edward Yellow & $-1.57 \mathrm{E}-16$ & -2.907 & 6.087 & 0.917 \\
\hline Idaho & $-1.19 \mathrm{E}-08$ & -1.217 & 9.033 & 0.960 \\
\hline
\end{tabular}

